\title{
A LESSON DESIGN OF ALGEBRAIC THINKING IN ELEMENTARY SCHOOL AS AN EFFORTS TO DEVELOP MATHEMATICAL LITERATION IN INDUSTRIAL ERA 4.0
}

\author{
Vira Pratiwi', Laely Farokhah ${ }^{2}$, Zaenal Abidin ${ }^{3}$ \\ ${ }^{1}$ Universitas Bhayangkara Jakarta Raya, Universitas Muhammadiyah Jakarta², Universitas \\ Muhammadiyah Surakarta ${ }^{3}$ \\ 1 vira.pratiwi@dsn.ubharajaya.ac.id \\ ${ }^{2}$ laely.farokhah@umj.ac.id \\ ${ }^{3}$ za825@ums.ac.id
}

\begin{abstract}
Algebraic thinking is one of the abilities needed in the industrial era 4.0. The efforts to instill algebraic thinking need to be done since elementary school students. Before students learn about algebra, they must have a lot of experience in making representations, abstractions, and generalizations. The ability to represent data using tables and diagrams is one indicator of algebraic thinking. This research was conducted discovery of learning obstacles thinking algebra by representing data using tables and diagrams in elementary school. Learning obstacles include ontogenical obstacles, epistemological obstacles, and didactical obstacles. Therefore, it is necessary to develop didactic designs to overcome these learning obstacles. The research method used was Didactical Design Research (DDR). This research was conducted by analyzing learning obstacles that were found to be used as the development of learning trajectories. The analysis process produces alternative didactic situations that can overcome obstacles in thinking algebra. Given that algebraic thinking in the curriculum in elementary schools is still implied, it is necessary to develop a comprehensive lesson design to facilitate students in developing algebraic thinking. The ability to think algebra is the high order thinking skills, they need to face various challenges today.
\end{abstract}

Keywords: Algebraic thinking, Didactic Design, Industrial era 4.0, Elementary School.

\begin{abstract}
Abstrak
Berpikir aljabar merupakan salah satu kemampuan yang dibutuhkan di era revolusi industri 4.0. Upaya menanamkan berpikir aljabar perlu dilakukan se-jak siswa sekolah dasar. Sebelum siswa belajar tentang aljabar, siswa harus memiliki banyak pengalaman dalam melakukan representasi, abstraksi, dan generalisasi. Kemampuan representasi data menggunakan tabel dan diagram merupakan salah satu indikator berpikir aljabar. Penelitian ini dilakukan karena ditemukannya learning obstacles berpikir aljabar dengan merepresentasikan data menggunakan tabel dan diagram di sekolah dasar. Learning obstacles tersebut meliputi ontogenical obstacles, epistemological obstacles dan didactical obstacles. Maka dari itu, perlu adanya pengembangan desain didaktis untuk mengatasi learning obstacles tersebut. Metode penelitian yang digunakan adalah Didactical Design Research (DDR). Penelitian ini dilakukan dengan cara menganalisis learning obstacles yang ditemukan untuk dijadikan sebagai pengembangan learning trajectory. Proses analisis tersebut menghasilkan alternatif situasi didaktis yang dapat mengatasi hambatan dalam berpikir aljabar. Mengingat bahwa berpikir aljabar pada kurikulum di sekolah dasar masih tersirat, maka perlu pengembangan lesson design secara komprehensif untuk memfasilitasi siswa dalam mengembangkan berpikir aljabar. Kemampuan berpikir aljabar merupakan berpikir tingkat tinggi yang dibutuhkan siswa untuk menghadapi berbagai tan-tangan yang dihadapi saat ini.
\end{abstract}

Kata Kunci: Berpikir Aljabar, Desain Didaktis, Era Industri 4.0, Sekolah Dasar. 


\section{INTRODUCTION}

Industry era 4.0 is here to replace the old order that is not following the demands of technological developments. This era is the beginning of the birth of a new model of interaction that is more innovative and massive. The scope of change is very broad, from the business world, banking, transportation, social, to education. Therefore this era provides two important choices namely lagging behind or following changes. Shifting the phenomenon of society that shifts activities that were originally carried out in the real world, into cyberspace. Likewise in the field of education that began to integrate the latest technology with learning.

Learning in an era of disruption requires students to have critical thinking competencies and problem-solving abilities (Effendy, 2019). The ability to think critically and the ability to solve problems is closely related to the ability of mathematical literacy, where good literacy skills will certainly help students to think critically and solve problems found in everyday life. These competencies are not only needed in the daily interaction of students with their environment, but also the interaction of students by sharing the kinds of technologies they use. Critical thinking and problem solving skills can be familiarized through learning algebraic thinking since elementary school.

Thinking algebra is different from thinking about aljabar. Algebra is studied after arithmetic starts at the junior high school level, but that is not the case with algebraic thinking (Hernandez, et al, 2010). Algebraic thinking in elementary schools is conceptualized more broadly so that the emphasis on algebra shifts from symbol manipulation activities towards algebraic reasoning or algebraic thinking. The scope of elementary school algebraic thinking includes generalization based on patterns, facts, phenomena or existing data, solving problems and communicating ideas through symbols, tables, diagrams, or other media to clarify the situation or problem (Alghtani and Abdulhamied, 2010).

The Habit of algebraic thinking needs to be done early because based on the results of several studies indicate that algebra is one of the materials that is difficult for middle school students. Preliminary research results show high school students have difficulties in learning the concepts and operations of algebraic arithmetic (Hidayati, 2010; Marsetyorini \& Murwaningtyas, 2012; Herutomo and Saputro, 2014; Permatasari, et al., 2015). Kilpatrick, et al. (2001) argue that in elementary and middle school mathematics curriculum must prepare students to learn algebra so that it includes attention to other mathematical domains. Therefore, through the habit of thinking algebra which since elementary school, is expected to reduce difficulties when studying algebra formally. Algebraic thinking is a thought activity that has 
proven difficult for students, and it is now widely recognized that students need earlier opportunities to engage in algebraic reasoning in elementary schools (NCTM, 2000; Kaput, 1999).

The development of elementary school algebra in different countries. Research conducted in America (Moyer, Huiker, \& Cai, 2004), Singapore (Fong, 2004), Russia (Schmittau and Moris, 2004), Korea (Lew, 2004), China (Cai, 2004), Aus- Tralia (Booker and Windsor, 2010) shows that the elementary school mathematics curriculum varies from country to country. Some countries that already have algebra started elementary school. Elementary school mathematics curriculum in Indonesia does not yet contain algebra but there are already some materials that can give rise to students' algebraic thinking in elementary schools (Pratiwi, Herman, \& Suryadi, 2017; Pratiwi, Herman, \& Suryadi, 2019).

Kilpatrick (2001) adds that before students arrive at formal learning about algebra, students must have a lot of experience in making representations, abstractions, and generalizing the relationship between numbers and arithmetic operations. Students must be familiar with algebraic ways of thinking to be proficient in manipulating algebraic symbols. In addition, students also need to learn the concepts of space, size, data, and opportunity in a way that connects them. There need to be activities to train algebraic thinking, one of which is through the experience of data representation.

At this time elementary school students can do the data presented in the form of tables and diagrams there is a thought process of students in presenting data into other representative forms. In addition, there is also an abstraction process from presentation in the form of tables to line diagrams. Algebra thinking activities can be done since elementary school students. Previous studies have shown that students have been able to develop algebraic thinking in elementary school. Booker \& Windsor's (2010) research results on seven-year-old elementary school students find those representation activities and problem solving with solutions obtained by students themselves in various steps in preparing to think algebra. Another way to develop algebraic thinking is by making generalizations from the solutions obtained. Mestre \& Oliviera (2012) show that fourth grade students have begun to develop algebraic thinking. The development of algebraic thinking begins with expressing generalizations of numerical relations in various representations. Radford Research (2010; 2011; 2012a; 2012b) found that non-symbolic algebraic thinking began to be exhibited by students at the age of seven to eight years.

64 | A LESSON DESIGN OF ALGEBRAIC THINKING IN ELEMENTARY SCHOOL AS AN EFFORTS TO DEVELOP MATHEMATICAL LITERATION IN INDUSTRIAL ERA 4.0 
Based on the results of several other studies, learning about algebraic thinking can begin at the elementary school level. In the elementary school curriculum, especially the 2013 mathematics curriculum for elementary schools relating to algebraic thinking has not been listed in writing. However, algebraic thinking can explicitly be developed starting from generalizing, patterning and solving problems. Algebraic thinking that occurs in elementary school age, starting from Second grade and deepened to Sixth grade. The trail is a good time to develop algebraic thinking in solving mathematical problems.

A preliminary study was also carried out on 40 students in grade fifth and grade sixth of elementary school. Found several learning obstacles that are grouped into several types, namely wrong in adding up scores and placing the results, less effective in making tables, mistakenly in concluding the contents of tables, do not know the concept of picture diagrams, obstacles in modeling into the form of images, wrong in interpreting problems, erroneous in determining the sequence of horizontal and vertical lines of information, do not know the concept of a line diagram, erroneous in predicting patterned growth, erroneously inferring the contents of a line diagram, and erroneous in choosing the right modeling. Based on the causes of the obstacles, learning obstacles that are found belong to the types of ontogenical obstacle, epistemological obstacle, and didactical obstacle. In addition, the obstclaes that occur are still conceptual and instrumental.

These obstacles must be minimized by maximizing the learning process. The teacher has an important role in the learning process, especially in overcoming obstacles experienced by students. The teacher can determine learning activities in class that can facilitate students in developing algebraic thinking skills. Learning that consists of a series of processes of preparation, implementation and evaluation must be carefully prepared. Through design based on research, it becomes an alternative to develop a design of students' algebraic abilities in elementary schools through a didactic situation analysis process, methadactic analysis and retrosfective analysis which is done in cycles.

Suryadi (2010) states that there are two fundamental aspects in the process of learning mathematics as stated above, namely the relationship of students with the material and the relationship of teachers and students, in fact it can create a didactic or pedagogical situation that is not simple even often very complex. Therefore, as a preparation of teaching materials must be designed so that students find concepts, procedures, or principles not directly but through correct ways of understanding. Thus, didactic activities that facilitate students to develop algebraic thinking and overcome student learning obstacles. 
Learning obstacles experienced by students can be predicted when the teacher designs the learning that will be presented. In addition, the teacher needs to analyze the difficulties in thinking algebra that is found. By analyzing learning obstacles faced by students, the teacher can present didactic designs in the form of Hypothetical Learning Trajectory (HLT) that can help students to develop algebraic thinking in accordance with learning sequences. Learning obstacles and learning trajectory are produced from a series of processes of interpretation of the meaning of a reality which is the impact of a didactic situation based on the hermeneutic paradigm. Design development is also produced by understanding meanings based on experience or phenomenology paradigms.

Thus, concrete efforts to interpret learning obstacles are found by developing a learning design that can develop algebraic thinking skills. One indicator of algebraic thinking is modeling mathematical problem situations using objects and representing using tables and diagrams, etc. Development of learning activities using didactic design research methods about thinking algebra in elementary schools that pay attention to learning obstacles. Then a study entitled " "Algebraic Thinking in Elementary School as an Efforts to Develop Mathematical Literacy in Industrial Era 4.0”.

\section{METHOD}

The research method used was Didactical design research. Suryadi (2010) explains that there are three stages in didactic research as follows, including prospective analysis including didactic situation analysis before learning in the form of a didactic design hypothesis including ADP, metape-didactic analysis, when implementing learning by taking into account the relationship of the right triangle, and retrospective analysis Retrosfective analysis that is analysis that links the results of the didactic hypothesis of the situation analysis with the results of the metric-tactical analysis. This research was conducted in three elementary schools in the city of Bandung and Garut regency. The participants in this study consisted of students from grade Fifth and grade sixth. In this research, as many as 35 students from grade Fifth as participants in the development of didactic designs and 50 students from grade sixth were involved in the preliminary study.

\section{RESULTS AND DISCUSSION}

\section{Results}


Learning Obstacles found in students are analyzed and used as a basis for developing lesson design. The results of the analysis are alternative didactic situations. Learning obstacles identified are ontogenical obstacle, didactical obstacle, and epistemological obstacle. Ontogenical obstacle is found because students do not understand the concept of the table or referred to as the conceptual ontogenical obstacle. Another ontogenical obstacle that is found is the lack of accuracy in adding and not understanding the use of commas in the problem. These errors are categorized as epistemological obstacle instrumental. In addition, there is an episte- mological obstacle as happened to students in drawing diagrams. Students understand the concept of picture diagrams, but when they get a new story situation, the data does not make a picture diagram correctly and is limited to the concept of bar charts, so when it comes to making other diagrams students are confused. The students' mistakes are conceptual epistemological types. Meanwhile, didactical obstacles occur in students because they do not experience learning to simplify the tension in the vertical and horizontal lines in the bar diagram. In addition, students lack experience in solving problems. This can be seen from the textbooks that are used not to facilitate students to do this and almost all students tend to do the same. In detail the learning obstacles found in students are as in Table 1.

Table 1. Analysis of Learning Obstacles

\begin{tabular}{|c|c|c|c|}
\hline No & Identified Difficulties & $\begin{array}{c}\text { Types } \\
\text { of Learning Obstacles }\end{array}$ & Alternative Didactic Situations \\
\hline 1 & $\begin{array}{l}\text { Mistaken in adding the } \\
\text { value and placing the } \\
\text { result. }\end{array}$ & $\begin{array}{l}\text { Ontogenical obstacle } \\
\text { and Didactical Obstacle }\end{array}$ & $\begin{array}{l}\text { Students analyze the appearance of tables and } \\
\text { gain experience reading tables found in everyday } \\
\text { life }\end{array}$ \\
\hline 2 & $\begin{array}{l}\text { Less effective in making } \\
\text { tables }\end{array}$ & Ontogenical Obstacle & $\begin{array}{l}\text { Students gain experience in how to read } \\
\text { appropriate tables and analyze parts of tables and } \\
\text { make tables based on the data provided. }\end{array}$ \\
\hline 3 & $\begin{array}{l}\text { Mistaken in concluding } \\
\text { the contents of the table }\end{array}$ & Ontogenical Obstacle & $\begin{array}{l}\text { Students gain experience interpreting the data in } \\
\text { the table and infer the overall message from the } \\
\text { table. }\end{array}$ \\
\hline 4 & $\begin{array}{l}\text { Do not know the } \\
\text { concept of a picture } \\
\text { diagram, Obstacles in } \\
\text { modeling in the form of } \\
\text { images }\end{array}$ & $\begin{array}{l}\text { Epistemological } \\
\text { Obstacle }\end{array}$ & $\begin{array}{l}\text { Students build knowledge of the concept of } \\
\text { drawing diagrams and their functions with the } \\
\text { proper meaning. } \\
\text { Students do modeling activities from the simplest } \\
\text { thing to the complex thing. Students model one } \\
\text { person with one animated picture. Then, two } \\
\text { people with one animated picture, etc. So students } \\
\text { understand the meaning of the representation of } \\
\text { the number of several people by one animated } \\
\text { picture. }\end{array}$ \\
\hline 5 & $\begin{array}{l}\text { Mistaken in interpreting } \\
\text { the problem }\end{array}$ & Ontogenical Obstacle & $\begin{array}{l}\text { The teacher facilitates students to interpret the } \\
\text { questions in each sentence carefully. }\end{array}$ \\
\hline 6 & $\begin{array}{l}\text { Mistaken in determining } \\
\text { the order of information } \\
\text { of horizontal and } \\
\text { vertical lines. }\end{array}$ & Ontogenical Obstcacle & $\begin{array}{l}\text { Students analyze the meaning of number lines and } \\
\text { their rules. } \\
\text { Students analyze the ideal bar charts found in } \\
\text { daily life. The teacher facilitates students to }\end{array}$ \\
\hline
\end{tabular}




\begin{tabular}{clll}
\hline No & Identified Difficulties & \multicolumn{1}{c}{$\begin{array}{c}\text { Types } \\
\text { of Learning Obstacles }\end{array}$} & \multicolumn{1}{c}{ Alternative Didactic Situations } \\
\hline 7 & $\begin{array}{l}\text { Don't know the concept } \\
\text { of line charts }\end{array}$ & $\begin{array}{l}\text { Epistemological } \\
\text { Obstacle }\end{array}$ & $\begin{array}{l}\text { conduct in-depth analysis, so that there are rules } \\
\text { in making bar charts. }\end{array}$ \\
\hline 8 & $\begin{array}{l}\text { Mistaken in predicting } \\
\text { patterned growth }\end{array}$ & $\begin{array}{l}\text { Didactical } \\
\text { Obstacle } \\
\text { meaning }\end{array}$ \\
\hline 9 & $\begin{array}{l}\text { Mistaken in concluding } \\
\text { the contents of the line } \\
\text { diagram }\end{array}$ & $\begin{array}{l}\text { The teacher facilitates students to do activities that } \\
\text { can improve the ability to make geometric and } \\
\text { numerical patterns. Then, present the results } \\
\text { obtained in various contexts. }\end{array}$ \\
\hline 10 & $\begin{array}{l}\text { Mistaken in choosing the } \\
\text { right modeling }\end{array}$ & $\begin{array}{l}\text { Epistemological } \\
\text { Obstcacle }\end{array}$ & $\begin{array}{l}\text { Students gain experience interpreting the data in } \\
\text { lane charts and infer the overall message from the } \\
\text { table. }\end{array}$ \\
\hline & $\begin{array}{l}\text { Students analyze the functions of tables and } \\
\text { diagrams. And conclude the effectiveness of the } \\
\text { table and each diagram in certain situations. }\end{array}$ \\
\hline
\end{tabular}

Lessons design consists of didactic situations, prediction of student responses, didactic anticipation, and assessment processes. Lesson design is designed in four meetings, the duration of each meeting is 2 x 35 minutes. The complete lesson design can be seen in the appendix. The main purpose of designing didactic design is to provide algebraic thinking experience by modeling problem situations using tables and diagrams. Lesson designs are designed to pay attention to the modeling process from the most concrete to the abstract. The modeling begins with the process of changing mathematical situations or mathematical problems using tables, then using picture diagrams, bar charts to line charts.

The design lessons designed have been applied as a whole. The implementation was carried out in four meetings over two days. The implementation found no significant obstacles. However, the set time duration is too short and needs to be added..

\section{Discussion}

Overall, the results of student test answers show that the material on tables and diagrams is difficult and not maximally mastered by students. After analysis, the causal factor arises from the ability of students who have not mastered the prerequisite material, teaching material that has not met the learning criteria according to several theories of learning situations. On the other hand, didactic obstacle is also caused by learning that does not pay attention to wrinkles (learning trajectory) in terms of the appropriate stages of thinking. This can be a barrier for students to learn. In addition, the complexity of the material also determines the success of learning. The material is sorted from simple materials to complicated material (Suryadi, 2010). 
One of the characteristics of a didactical obstacle is that most students tend to make the same mistakes.

On the other hand to trace the occurrence of learning obstacles, an analysis of learning is conducted by paying attention to the pedagogical philosophical theory of Harel (2008) which includes mental acts, ways of thinking and ways of understanding. In addition, an analysis of learning trajectories is also carried out by paying attention to the material wrangling, the material before and after it. Thus, learning is seen from various viewpoints of relevant theories. Based on the results of the analysis, learning that occurs has not facilitated students to form a scheme. Schemas for certain pieces of mathematics are individual collections of actions, processes, objects, and other schemes that are linked in a framework to the individual mind in dealing with a mathematical problem. Schemes that are formed through a process. In addition, learning should contain for the unity, flexibility and coherence that is summarized in methadacttive activities. There are student and teacher activities during the discussion of the material, response prediction and anticipation designs that are flexible to the didactic and pedagogical situations that occur, and the ability of the teacher to maintain the HD, mobile, and ADP relationships in the didactic triangle remain consistent and coherent in dynamic learning (Suryadi, 2012).

Didactical obstacles are found by analyzing teaching materials which do not include validation and institutional activities as one aspect of didactic situation theory by Brosseau (2002). This situation gives value to the truth of the knowledge learned in class. This is related to concepts, symbols, and knowledge that might be used at different times and for different purposes. The teaching material used contains action situations and formulations.

Ontogenical obstacle that is found dominant is conceptual and a small part is instrumental. Learning obstacles that are conceptual include students not being able to make tables. Figure charts, bar charts and line charts. This is due to the limitations of students in knowing the concept of data representation using tables and diagrams. This type of obstacle is commonly found in students. While learning instrumental obstacles include students being less thorough in adding upgrades, mistaken in reading questions, etc. This type of error is caused because students feel rushed in working. Some students also felt that the time allotted to do some activities in doing worksheets was too short, for example in working on problem solving problems, making tables or even in discussions. 
The epistemological obstacle that occurs is conceptual. Errors experienced by students include in making diagram drawings and in solving problems related to line diagrams. Errors found in students who make diagram drawings occur because students do not know the representation in the form of diagram drawings. The most important thing in data representation is to display it in another form without reducing the quantity of data and becoming more effective for the public to read. Students have been able to display in other forms without reducing the quantity, but the representations made have not been effective and in accordance with the rules of the drawing diagram. While in the process of solving problems, ob-stacles that occur students can not determine the representation in accordance with the context of the story contained in the problem. Although data can be represented in various forms, students must understand and be able to determine the right and most effective form of representation.

Didactical obstacle was found to be instrumental. Students cannot make effective tables and cannot solve problem solving related to bar charts. Students feel there is nothing wrong in making tables, because students get material from the learning process. This was found when analyzing the learning process in the class. In addition, students are not accustomed to working on problem solving problems in the learning process, so students cannot work on the problems given. Both of these things happen to some students who work on test questions.

The results of the analysis of the causes of learning obstacles are used as alternative didactic situations in the development of lesson design. Commonly produced didactic alternatives include reading tables and diagrams, interpreting data, creating, implementing them in solving mathematical problems related to tables and diagrams. This didactic situation is the basis for developing lesson de-sign at a later stage. Learning trajectories that are designed based on learning obstacles are found and the confusion between the material. After knowing the material wrinkles, then determined some of the material that is raised and explored more deeply to bring up learning situations that can develop the ability to think algebraic. In addition, material tables and diagrams are designed from the most concrete to the most abstract so that students can interpret gradually based on the conditions of thinking of elementary school students.

The learning trajectory that is designed consists of prerequisite materials, core material and further related material. Understanding that learning between materials is interrelated and 
relevant, the learning trajectory is arranged comprehensively and meaningfully. Paying attention to various aspects of compiling learning trajectories is expected to be developed into didactic designs of algebraic thinking that can be used in general. Material that is a prerequisite is the concept of integers and number lines, the concept of vertical and horizontal lines, and the concept of rectangular flat shapes, as well as po-la. The prerequisite material must be mastered by students before lesson design is implemented.

The core material to develop the ability to think algebra in material tables and diagrams is the representation of data using tables, picture diagrams, line diagrams, and line diagrams. The flow of thinking that is built is the ability of students to model problem situations in tabular form. At the beginning of modeling, students move data from the form of stories into tabular form. Table representation is the beginning of a simple equality way of thinking. Students create other forms of existing data without reducing the amount of quantity in a more effective form. This way of thinking occurs when students draw pictures, bar charts, and line charts. In addition, representation is made from the semi-abstract form of the table, then into the form of a diagram of an image that begins modeling in the form of images, then modeling the shape of the bar to form a line diagram. Learning paths formed from the start of representation using tables to line diagrams, each move from one data representation to another is interspersed with problem solving related to the material. This is done as a process of institutionalization in didactic situation theory that seeks to be applied in learning. Material related afterwards includes pie charts, mean, median, and other introductory statistics. This material will be mastered by students if the data representation using tables and diagrams has been mastered by students. Therefore, it is important to know the material before and after the core material to be connected in full learning. The connections that are made between material will form knowledge that is useful and useful for the life of students.

Basically the development of design lessons to one to four has the same pattern. Only finish the conversation discussed at the obstacle that happened. The lesson design consists of some exercises, introductory discussions, formulation of steps, open questions or problem solving and closing activities including connecting with further material.

Each design lesson begins with a discussion held to motivate students and gain experience about tables and diagrams in daily life. For school-age students this is very 
important. Given the psychological condition of elementary school students. Readiness to learn and accept lessons depends on the material that students are interested in.

In addition, in each lesson design there are also activity formulation steps in either making tables or diagrams. The formulation is the culmination of learning stages in tactical situation theory that allows students to understand certain concepts. Students discover their own concepts that are formulated by mutual agreement after going through the discussion process. Concepts that are successfully formulated by students themselves can last longer than instant concept support by teachers (Harel, 2008).

Other didactic situations that exist in each design lesson are carried out open ended problems or problem solving. Secondly expect this to have more people thinking about algebra (Suherman, et al, 2003). One indicator is modeling. Modeling problems through tables and diagrams can be explored through open ended questions and problem solving.

\section{CONCLUSION}

Learning obstacles identified are ontogenical obstacle, didactical obstacle, and epistemological obstacle. Therefore a learning trajectory was arranged which was designed as a basis for developing didactic designs of algebraic thinking. The learning path that is designed consists of prerequisite materials, core material, and further related material. Understanding that learning between materials is interrelated and relevant, learning trails are arranged comprehensively and meaningfully. Paying attention to various aspects in compiling the learning trajectory is expected to be developed into a didactic design of algebraic thinking that can be used in general. Lessons design consists of didactic situations, prediction of student responses, didactic anticipation, and assessment processes. The lesson design is designed in four meetings, the duration of each meeting is 2 x 35 minutes. The complete lesson design can be seen in the appendix. The main purpose of designing didactic design is to provide algebraic thinking experience by modeling problem situations using tables and diagrams. The lesson design are designed to pay attention to the modeling process from the most concrete to the abstract. The modeling begins with the process of changing mathematical situations or mathematical problems using tables, then using picture diagrams, bar charts to line charts. The design lessons designed have been applied as a whole. The implementation was carried out in 
Journal of Elementary Education

Volume 3, Number 2, September 2019
P-ISSN: 2580-9326

E-ISSN: 2580-7714

four meetings over two days. The implementation found no significant obstacles. However, the set time duration is too short and needs to be added.

\section{ACKNOWLEDGMENTS}

We would also like to show our gratitude to the corespondent authors for sharing their pearls of wisdom with us during the course of this while writing the article, and we thanks to teachers in elementary school. We are also immensely grateful to primaryedu journal for their comments on an earlier version of the manuscript, although any errors are our own and should not tarnish the reputations of these esteemed persons.

\section{REFERENCES}

Alghtani, O.A. \& Abdulhamied, N.A. (2010). The effectiveness of geometric representative approach in developing algebraic thinking of fourth grade students. Procedia - Social and Behavioral Sciences, 8 (5), 256-263. https://doi.org/10.1016/j.sbspro.2010.12.035

Booker, G., \& Windsor, W. (2010). Developing algebrain c thinking: Using problem-solving to build from number and geometry in the primary school to the ideas that underpin algebra in high school and beyond. Procedia - Social and Behavioral Sciences, 8(5), 411-419. https://doi.org/10.1016/j.sbspro. 2010.12.057

Brousseau, G. (2002). Epistemological Obstacles, Problems, and Didactical Engineering . Theory of Didactical Situations in Mathematics: Didactique Des MathEmatiques, 1970 1990 , (1 983), 79-117. Cai, J. (2004). Developing Algebraic Thinking in the Earlier Grades : A Case Study of the Chinese Elementary School Curriculum 1. The Mathematics Educator, 8(1), 107-130.

Fong, N. S. (2004). Developing Algebraic Thinking in Early Grades: Case Study of The Singapore Primary Mathematics Curriculum. The Mathematics Educator. Vol. 8 No. 1. 3959.

Harel, G. 2008. What Is Mathematics? A Pedagogical Answer to a Philosophical Question. (PP 1-26) Washington: The Mathematical Association of America, Inc.

Herutomo, R. A. \& Saputro, T. E. M. (2014). Analisis Kesalahan dan Miskonsepsi Siswa Kelas VII Pada Materi Aljabar. Edusentris, Jurnal Ilmu Pendidikan dan Pengajaran, Vol. 1 No. 2, hal. 134-145.

Hernandez, I., Levy, R. \& Brown, S. (2010). Algebraic Reasoning in Elementary School Students. USA: Harvey Mud 
Hidayati, F. (2010). Kajian Kesulitan Belajar Siswa Kelas VII SMP Negeri 16 Yogyakarta dalam Mempelajari Aljabar. Skripsi Universitas negeri Yogyakarta. Dipublikasikan

Kilpatrick, J., Swafford, J. \& Fidell, B. (2001). Adding It Up: Helping Children Learn Mathematics. Washington, DC: national Academy Press.

Lew, H. C. (2004). Developing Algebraic Thinking in Early Grades: Case Study of Korean Elementary School Mathematics. The Mathematics Educator. Vol. 8 No. 1. 88-106.

Marsetyorini, A. D. \& Murwaningtyas, C. E. (2012). Diagnosis Kesulitan Belajar Siswa dan Pembelajaran Remedial dalam Materi Operasi Pada Pecahan Bentuk Aljabar Di Kelas VIII SMPN 2 Jetis Bantul. Prosiding Makalah dipresentasikan dalam Seminar nasional Matematika dan Pendidikan Matematika "Kontribusi Pendidikan Matematika dan Matematika dalam Membangun Karakter Guru dan Siswa”. Jurusan Pendidikan Matematika FPMIPA UNY

Mestre, C, \& Oliveira, H. (2012). From Quasi-Variable Thinking to Algebraic Thinking: A Study With Grade 4 Students. [Online]. Diakses dari http://repositorio.ul.pt/bitstream/ 10451/7087/1/Mestre_Oliveira_ICME12.pdf

Moyer, J., Huinker, D. A. \& Cai, F. (2004). Developing Algebraic Thinking in the Earlier Grades: A Case Study of the U.S. Investigations Curriculum. The Mathematics Educator. Vol. 8 No. 1. 6-38.

NCTM. (2000). Principles and Standards for School Mathematics. Reston, V.A: NCTM.

NCTM.(2014). Principles to Actions: Ensuring Mathematical Success for All. Reston, V.A: NCTM.

NCTM. (2000). Principles and Standards for School Mathematics. Reston, V.A: NCTM.

Permatasari, B. A. D., dkk. (2015). Analisis Kesulitan Siswa dalam Menyelesaikan Soal Materi Aljabar Siswa Kelas VIII SMP Negeri 2 Bangil. Kadikma, Vol. 6, No. 2, hal 119-130.

Pratiwi, V., Herman, T., dan Suryadi, D. (2017). Upper Elementary Grades Students' Algebraic Thinking Ability In Indonesia. IJAEDU- International E-Journal of Advances in Education. 3 (9) 705-715

Pratiwi, V., Herman, T., dan Suryadi, D. (2019). Algebraic thinking obstacles of elementary school students: A Hermeneutics-phenomenology study. IOP Publishing Journal of Physics: Conference Series. 1157 (3) 032115 
Journal of Elementary Education

Volume 3, Number 2, September 2019
P-ISSN: 2580-9326

E-ISSN: 2580-7714

Radford, L. (2010). Elementary Forms of Algebraic Thinking in Young Students. In M. F. Pinto. \& T. F. Kawasaki (Eds.). Proceedings of the 34th Conference of the International Group for the Psychology of Mathematics Education, Vol. 4, pp. 73-80. Belo Horizonte, Brazil: PME.

Radford, L. (2011). Embodiment, perception and symbols in the development of early algebraic thinking. In Ubuz, B. (Ed.), Proceedings of the 35th Conference of the International Group for the Psychology of Mathematics Education (Vol. 4, pp. 17-24). Ankara, Turkey: PME.

Radford, L. (2012a). Early Algebraic Thinking Epistemological, Semiotic, and Developmental Issues. 12th International Congress on Mathematical Education, Seoul, South Korea.

Suherman, E., dkk. (2003). Strategi Pembelajaran Matematika Kontemporer (Common Text Book Edisi Revisi). Bandung: Jica

Suryadi, D. (2010). Didactical Design Research (DDR) Dalam Pengembangan Pembelajaran Matematika1. Seminar Nasional Pembelajaran MIPA Di UM Malang, 13 November 2010 SEMNAS MIPA 2010 UTAMA, (November), 1-75. 